\title{
KLASIFIKASI BENTUK KATA BILANGAN BAHASA MELAYU JAMBI
}

The Classification of Numeral Forms in Jambi Malay

\author{
Ade Rahima
}

Universitas Batanghari Jambi

ade.rahima@unbari.ac.id

\begin{abstract}
Abstrak
Tujuan penelitian ini yaitu untuk mendeskripsikan klasifikasi bentuk kata bilangan bahasa Melayu Jambi (BMJ). Metode yang digunakan dalam penelitian ini adalah metode deskriptif dengan pendekatan struktural. Sumber data penelitian mencakup data lisan yang berasal dari informan dan data tulisan yang diambil dari kumpulan cerita rakyat daerah Jambi. Secara keseluruhan penelitian ini dilakukan di dua lokasi yakni Kabupaten Muaro Jambi dan Kota Jambi. Data penelitian berupa kata, frasa dan kalimat-kalimat yang mengandung kata bilangan BMJ. Teknik pengumpulan data yang digunakan meliputi teknik wawancara, observasi, introspeksi, dan elisistasi. Analisis data dilakukan dengan metode distribusional melalui teknik subsitusi, ekspansi dan permutasi. Hasil analisis data menunjukkan bahwa secara umum bentuk kata bilangan BMJ dapat diklasifikasikan atas 2 bentuk yakni: 1) bentuk dasar yang mencakup bentuk monomorfemis dan bentuk polimorfemis. Kedua bentuk ini diklasifikasikan berdasarkan jumlah morfemnya. 2) bentuk kompleks atau turunan diklasifikasikan berdasarkan proses morfologisnya, yakni bentuk berafiks dan bentuk reduplikasi. Berdasarkan hasil analisis dapat disimpulkan bahwa klasifikasi bentuk kata bilangan bahasa BMJ merupakan kajian linguistik dari aspek morfologi dan sintaksis mempunyai klasifikasi tersendiri yang berbeda dari bentuk kata lainnya.
\end{abstract}

Kata kunci: klasifikasi, betuk, kata bilangan, bahasa Melayu Jambi.

\begin{abstract}
The objective of this research is to describe the classification of numeral forms in the Jambi Malay Language. The method used in this research is descriptive. Sources of research data include oral data from informants and written data taken from a collection of Jambi folklore. Overall this research was conducted in two locations, namely the district of Muaro Jambi and Jambi city. The research data were in the form of words, phrases, and sentences containing Jambi Malay Language numeral forms. The techniques collection used include interview, observation, introspection, and elicitation techniques. Data analysis is done by distributional method through substitution, expansion, and permutation technique. The results of data analysis showed that the numeral forms of Jambi Malay Language can be classified into 2 forms namely: 1) Basic form that includes monomorphemic form and polymorphemic form. Both forms are classified based on the amount of morphemes. 2) Complex forms or derivatives are classified based on their morphological processes, i.e. forms of affixed and reduplication. Based on these results, it can be concluded that from the morphological and syntactic aspects,
\end{abstract}


the numeral forms of Jambi Malay Language has its own classification which is different from other word forms.

Key words: clasification, numeral forms, Jambi Malay Language.

How to Cite: Rahima, Ade. (2021). Klasifikasi Bentuk Kata Bilangan Bahasa Melayu Jambi. Ranah: Jurnal Kajian Bahasa. 10(1). 101--109. doi: https://doi.org/10.26499/rnh.v10i1.3563

\section{PENDAHULUAN}

Masalah pengklasifikasian kata bilangan dalam bahasa Melayu Jambi (BMJ) menarik untuk dikaji dengan ditemukannya fenomena bentuk kata bilangan sekok yang berarti "satu" dan kata bilangan sekok yang bermakna 'seekor, sepotong, seorang, sebuah dan sejenisnya'. Kedua bentuk kata tersebut tidak berbeda bentuk dan pemakaiannya oleh masyarakat penuturnya. Namun, dari fungsi dan makna kata tersebut terlihat ada perbedaan dan hal ini terkait dengan pengklasifikasian kata bilangan.

Di sisi lain, persoalan perbedaan pengklasifikasian kata bilangan oleh beberapa pakar bahasa Indonesia perlu dicermati. Hal ini disebabkan perbedaan sudut pandang para ahli dan teori yang digunakan. Alwi et al., (2003), mengklasifikasikan kata bilangan ke dalam kelas verba yang dapat dinegatifkan dengan kata "tidak". Kridalaksana (2005), justru melihat dari distribusi kata bilangan secara tersendiri yakni kata yang tidak dapat bergabung dengan kata "tidak" dan "sangat". Selain itu, Samsuri (1994) menggolongkan kata bilangan ke dalam klasifikasi kelas kata utama yang berbeda dari nomina, verba dan adjektiva. Selanjutnya, para ahli dan peneliti bahasa tersebut juga mengemukakan sub-klasifikasi kata bilangan yang berbeda-beda. Menurut Shibatani (2016: 22), pengkalisifikasian kata memiliki berbagai fungsi antara lain sebagai penanda bilangan dalam kalsifikasi kata bilangan, penada nominal dalam nominalisasi, penanda kalausa relatif dan ekspresi anoforis dalam suatu wacana.

Berdasarkan penelusuran kepustakaan, khususnya kajian tentang kata bilangan belum banyak mendapat perhatian. Beberapa penelitian yang terpublikasi yang dilakukan lima tahun terakhir oleh peneliti bahasa daerah di Indonesia, antara lain: Kata bilangan dalam bahasa Sunda (Anjarsari, 2015), Numeralia Bahasa Melayu Dialek Kapuas Hulu Kajian (Lestari et al., 2017), Numeralia dan Adjektiva dalam Bahasa Indonesia (Kusumawati, 2019), dan Kata Bilangan Bahasa Ragam Abun Ta. Distrik Bikar Kabupaten Tambrauw. (Soulisa et al., 2020).

Bahasa Melayu Jambi baru mulai diteliti pada tahun 1981 oleh Tim dari Pusat Pembinaan dan Pengembangan Bahasa yang diketuai oleh Nurzuir Husin, yakni tentang masalah Struktur Bahasa Melayu Jambi. Penelitian kedua, Pemetaan Bahasa Daerah Riau dan Jambi (1982/1983), juga oleh tim dari Pusat Bahasa yang diketuai oleh Saidat Dahlan. Penelitian ketiga, Prefiksasi Bahasa Jambi Seberang Kota (1983) oleh Mujiono Wiryotino. Penelitian keempat, Morfosintaksis Bahasa Melayu Jambi (1986) oleh Husin dkk. Penelitian yang mengkaji masalah kata bilangan BMJ baru disinggung secara sepintas dalam dua penelitian yakni pada Penelitian Struktur dan Morfosintaksis BMJ (Nurzuir, 1986a, 1986b).

Dalam penelitian Struktur BMJ, kata bilangan disinggung dalam masalah reduplikasi. Salah satu bentuk reduplikasi dalam BMJ adalah reduplikasi kata bilangan, seperti sekok-sekok, 'satu-satu', duo-duo, 'duo-duo', tigo-tigo, 'tiga-tiga', dan mpat-mpat, 'empat-empat' (Nurzuir, 1986a). Selain itu, dalam penelitian Morfosintaksis BMJ, secara implisit kata bilangan disinggung pula dalam pembahasan frasa nomina. Para peneliti mengungkapkan bahwa frasa nomina (selanjutnya FN) dalam BMJ ada yang berunsur kata bilangan, seperti pada frasa Mpat ekok papan ' empat ebuah papan', sekok ular, 'seekor ular', dan tigo ekok manggo, 'tiga buah mangga' (Nurzuir, 1986b). Gambaran dari kedua hasil penelitian yang 
dilakukan oleh Husin dkk. belum mengungkap klasifikasi kata bilangan BMJ secara jelas. Di sisi lain, pemakaian kata bilangan BMJ sangat penting baik secara formal bertujuan untuk menyampaikan pesan-pesan pembangunan kepada masyarakat di Provinsi Jambi. Secara nonformal kata bilangan digunakan untuk komunikasi sehari-hari seperti dalam aktivitas jualbeli, lamaran, peringatan hari kelahiran dan hari kematian.serta upacara adat lain. Menurut Rahima \& Juwanda (2019: 9) sampai saat ini, bahasa Melayu Jambi termasuk kata bilangan dipakai secara luas, termasuk para pendatang yang bekerja atau berbisnis di provinsi Jambi.

Berdasarkan uraian latar belakang tersebut, maka fokus masalah penelitian ini yaitu: Bagaimanakah klasifikasi kata bilangan BMJ dari aspek morfosintaksis? Tujuan penelitian ini untuk mendeskripsikan tentang klasifikasi bentuk-bentuk kata bilangan BMJ dari aspek morfosintaksis.

\section{LANDASAN TEORI}

Istilah kata bilangan yang digunakan dalam penelitian ini merupakan alih-alih dari istilah numeralia. Peneliti memilih istilah kata bilangan karena istilah tersebut lebih dikenal masyarakat secara umum dari pada istilah numeralia. konsep kata bilangan yang digunakan dalam penelitian ini mengacu pada pendapat Kridalaksana (2005), Alwi et al., (2003) dan Kusumawati (2019) menjelaskan bahwa kata bilanganyaitu kata yang dapat digunakan untuk membilang banyaknya orang, binatang, barang, hal atau konsep. Secara leksikal kata bilangan atau numeralia yaitu kata (atau frasa) yang menunjukkan bilangan atau kuantitas; kata bilangan (KBBI, 2016) yaitu "kata (atau frasa) yang menunjukkan bilangan atau kuantitas".

Berdasarkan beberapa pendapat dan makna leksikal dari kata bilangan maka dapat disimpulkan bahwa kata bilangan merupakan kata atau frasa yang secara semantis mengacu pada kuantitas. Kuantitas mencakup bilangan, jumlah, tingkat dan kumpulan. Sedangkan secara gramatikal kata bilangan merupakan klasifikasi yang dapat digunakan untuk menghitung banyaknya sesuatu baik benda, peristiwa, dan konsep.

Klafikasi bentuk kata bilangan BMJ dikaji secara morfosintaksis. Oleh karena itu, secara teoretis penelitian ini melibatkan teori morfologi dan sintaksis. Untuk mengidentifikasikan morfem-morfem yang terdapat pada setiap bentuk kata bilangan BMJ digunakan teori morfologi Nida (1979), J.S, (1993) dan. Teori Lyons (2012) digunakan untuk mengidentifikasikan ciri-ciri kata yakni kata bilangan BMJ. Selanjutnya, untuk menganalisis kata bilangan BMJ beserta paradigma, sehubungan dengan afiksasi yang menghasilkan kata bilangan digunakan teori Matthews (1974) yang dikembangkan dari teori Hockett (1958). Teori ini meliputi model analisis morfologi yang meliputi Word and Paradigma (WP) dan Item Process (IP), sebagai pembanding digunakan teori Morfologi dari Kridalaksana (2005). Sedangkan masalah klaifikasi dan subkategori kata bilangan BMJ dibahas menggukan teori R. Horn (1989), sebagai pembanding digunakan teori Kridalaksana, (2005) dan Tarigan (1988).

Konsep morfosintaksis dalam penelitian mengacu pada pendapat Samsuri (1994), Djawanei (1983), Kridalaksana (2005) dan Samsuri (1994). Penelitian morfosintaksis ditentukan oleh bentuk dan pengertian. Selanjutnya beliau menjelaskan bahwa bentuk dan pengertian tersebut merupakan satu komposit karena pengertian itu diberikan oleh bentuk atau kadang-kadang tak ada bentuk. Berdasarkan konsep ini jelas bahwa bahasa itu mempunyai beberapa pengertian yang tidak hanya ditentukan oleh satu bentuk morfologi yang biasa mengandung makna leksikal, tetapi juga ada makna gramatikal yang muncul dari keseluruhan hubungan distribusi unsur-unsur lain seperti morfem dengan kata, kata dengan kata lain yaitu dalam frasa atau tataran sintaksis.

Selain itu, Djawanei (1983) mendefinisikan bahwa morfosintaksis bertujuan menyelidiki dan membahas morfem yang mempunyai fungsi sitaksis dan membawa makna 
gramatikal (hlm. 4). Berbeda dengan Djawanei, Kridalaksana (2005) mendefinisikan bahwa morfosintaksis adalah struktur bahasa yang mencakup morfologi dan sintaksis suatu organisasi deskripsi tentang kaidah-kaidah yang mengatur kombinasi morfem dalam satu-satuan yang lebih besar. Dalam penelitian ini, kombinasi morfem dalam satuan yang lebih besar dibatasi pada tataran frasa yang membawa fungsi sintaksis dan mengandung makna gramatikal.

Berdasarkan ketiga konsepsi morfosintaksis yang dikemukakan ketiga pakar bahasa tersebut, jelaslah bahwa penelitian ini mencakup bidang garapan proses morfemis yang menimbulkan fungsi sintaksis baru. Perubahan bentuk kata sebagai akibat dari proses morfemis mencakup afiksasi, reduplikasi. Proses morfemis dapat menimbulkan fungsi sintaksis baru, apabila kata-kata hasil proses tersebut berbeda dari bentuk asalnya dan perbedaan bentuk tersebut terdapat dalam hubungan sintaksis. Fungsi gramatika dan makna kata-kata yang mengalami proses morfemis itu membawa akibat logis, terhadap sifat-sifat bentuk baru dalam hubungannya dengan kata lain.

\section{METODE PENELITIAN}

Metode yang digunakan dalam penelitian ini adalah metode deskriptif. Tujuan metode deskriptif yaitu untuk mendeskripsi, menggambarkan, secara eksplisit, sistematis, faktual, akurat mengenai data atau fenomena yang akan diteliti (Sudaryanto, 1992; T Fatimah, 2006; Tarigan, 1988).

Metode dan teknik yang digunakan untuk pengumpulan data tersebut meliputi teknik wawancara, observasi, introspeksi dan elisistasi. 1) Wawancara, pencatatan dan perekaman, teknik ini dilakukan dengan berpedoman pada pedoman wawancara yang telah disiapkan sedemikian rupa sesuai dengan masalah yang diteliti. 2) Observasi dilakukan untuk memperhatikan pemakaian kata bilangan BMJ di lingkungan masyarakat Jambi. Hal ini juga bertujuan untuk mengecek kebenaran korpus yang diperoleh. 3) Introspeksi, peneliti mengumpulkan data berdasarkan intuisi bahasa peneliti. Hal ini dilakukan karena peneliti penutur asli yang mampu memahami dan menggunakan BMJ secara spontan dalam dialog yang beranekaragam. 4) Elisitasi digunakan untuk memancing data dari informan bila data meragukan.

Metode distribusional merupakan metode analisis bahasa yang memerikan unsur-unsur bahasa dalam satuan yang lebih besar, misalnya kata dalam frasa, frasa dalam klausa dan klausa dalam kalimat (Kridalaksana, 2005; T Fatimah, 2006). Dalam penelitian ini unsur bahasa yang diperikan meliputi unsur morfem dalam kata dan kata dalam frasa. Metode ini diterapkan melalui teknik substitusi, teknik ekspansi dan teknik permutasi.

Dalam penelitian ini teknik substitusi digunakan untuk mengetahui apakah satu-satuan kata bilangan termasuk klasifikasi yang sama atau berbeda. Teknik ekspansi dilakukan dengan cara memperluas satuan lingual yang dianalisis. Dalam penelitian teknik tersebut, bertujuan untuk melihat daya gabung kata bilangan dengan satuan lain, pola urutannya dan makna apa yang terkandung dalam satuan-satuan lingual tersebut. Teknik permutasi diterapkan dengan memindahkan posisi atau letak satuan lingual yang dianalisis (dalam hal ini kata bilangan) ke depan atau ke belakang satuan lingual lain untuk melihat keketatan hubungannya antar satuan lingual.

Metode memuat informasi mengenai macam atau sifat penelitian, data dan sumber data, teknik pengumpulan data, instrumen pengumpulan data, prosedur pengumpulan data, dan metode analisis data. Penelitian kuantitatif perlu mencantumkan teknik pengujian hipotesis yang relevan. 


\section{PEMBAHASAN}

Berdasarkan hasil analis data maka kata bilangan BMJ dapat klasifikasikan berdasarkan jumlah morfem pembentuknya. Klasifikasinya mencakup dua bentuk yakni: 1) bentuk dasar yang terdiri dari satu morfem atau monomorfemis, dan 2) bentuk kompleks yang terdiri dari banyak morfem atau polimorfemis. Klasifikasi bentuk-bentuk tersebut akan dijelaskan sebagai berikut.

\section{Klasifikasi Terdiri Dari Satu Morfem atau Monomorfemis}

a) Monomorfemis dengan satu suku kata

Klasifikasi bentuk kata bilangan monomofemis yang ditemukan berjumlah dua buah yaitu: (1) mpat 'mpat', (2) nam 'nam'. Bentuk-bentuk kata bilangan ini digunakan dalam bahasa sehari-hari atau bahasa percakapan seperti pada data berikut:

(1) Di dusun ko ado mpat sanggar batek. 'Di dusun ini ada empat sanggar batik'.

(2) Kami nam bedulur galoe. 'Kami enam bersaudara semuanya'.

\section{b) Monomorfemis dengan dua suku kata}

Kata bilangan monomorfemis yang terdiri atas dua silabel dapat dilihat pada data berikut: 1) se-kok 'satu', 2) du-o 'dua', 3) Ti-go 'tiga', 4) tujoh 'tujuh'. Penuturan BMJ menggunakan bentuk sekok dalam dua bentuk yakni sekok 'satu' dan sekok ------ >se + ekok (KPN) 'sebuah'. Kedua bentuk itu secara morfologis berbeda, walaupun wujud lahirnya sama. Sekok yang termasuk bentuk kata bilangan monomorfemis memiliki makna yang utuh yakni 'satu'. Sedangkan sekok yang berbentuk polimorfemis, berasal dari bentuk se- + ekok. Perbedaan kedua bentuk ini dapat dilihat dari distribusi dan pemakaian kedua kata itu dalam tataran sintaksis. Bentuk kata bilangan monomorfemis tiga silabel jumlahnya juga terbatas. Dalam penelitian ini, hanya ditemukan empat buah data yang tergolong bentuk tersebut yakni: 1) semilan 'sembilan', 2) seluroh 'seluruh' (3) bebagai 'berbagai' (4) segalo 'segala'

\section{Klasifikasi Bentuk Kata Bilangan Polimorfemis}

Kata bilangan polimorfemis merupakan bentuk turunan kata bilangan dasar (monomorfemis) yang telah mengalami proses morfologis Proses morfologis yang mengubah bentuk dasar (D) menjadi bentuk turunan mencakup bentuk-bentuk:

polimorfemis dengan afiksasi, 2) polimorfemis dengan reduplikasi, dan 3) polimorfemis dengan penggabungan bentuk berafiks dan bentuk ulang. Proses morfologis ini menghasilkan kata bilangan berafiks, bentuk ulang kata bilangan, dan bentuk gabungan.

a) Polimorfemis dengan Prefiks

Prefiks yang melekat pada D membentuk kata bilangan polimorfemis ada tiga yakni: prefik se-, prefik be-dan prefiks ke. Dalam BMJ prefiks se- merupakan prefiks pembentuk kata bilangan yang paling luas distribusinya. Selain muncul dengan D yang praklasifikasial, juga dapat muncul dengan $\mathrm{D}$ yang berklasifikasi nomina $(\mathrm{N})$, dan verba $(\mathrm{V})$, seperti data berikut:
(3) se- + ekok ------ > sekok 'sebuah', seekor
(4) se- + blas ------- > seblas 'sebelas'
(5) se- + tumbuk ---- > setumbuk 'sepuluh meter'
(6) se- + kodi ------- > sekodi 'sekodi'
(7) se- + pelimo ----- > sepelimo 'seperlimo'

Pada bagian terdahulu telah dikemukakan bahwa kata bilangan sekok yang berbentuk polimorfemis pada data (3) se- + ekok. Prefiks se- setelah melekat pada kata penggolong 
nomina (KPN) ekok, mengalami reduksi yakni peluluhan salah satu fonem /e/. Dalam tataran sintaksis kata bilangan sekok ini dapat bersubstitusi dengan bentuk-bentuk polimorfemis lainnya seperti duo ekok, "dua buah" tigo ekok, tiga buah" dan mpat ekok "empat buah". dan berapo ekok 'berapa buah.

Selanjutnya prefiks se- yang melekat pada D yang berklasifikasi N sekaligus berfungsi membentuk kata bilangan polimorfemis yaitu se+blas 'sebelas', se+tumbuk 'satu tumbuk', dan se+kodi 'satu kodi', dan se+lusin 'satu lusin'. Sedangkan pada bentuk sepelimo 'seperlima 'prefiks se- melekat pada D verba pelimo 'perlima'. Dapat disimpulkan satu kaidah kemunculan prefiks se- yang membentuk klasifikasi kata bilangan adalah: $\mathrm{Se}+\mathrm{N}$ (KPN) /V).

Dibandingkan dengan prefiks se-, maka prefiks be- mempunyai distribusi yang lebih terbatas. Prefiks be- hanya dapat dilekatkan pada bentuk dasar kata bilangan atau bentuk KG. Dengan demikian, prefiks be- memiliki kaidah kemunculan yaitu (be-+Num/N). Kaidah ini berlaku antara lain dapat dilihat pada untuk data:

(11) Budak beduo ko lalu becarito, 'Anak berdua ini lalu bercerita'.

(12) Kamu ko betigo beradiklah tingal dirumah ini.. 'Kamu bertiga beradiklah tinggal dirumah ini'.

Prefiks be- yang dilekatkan pada D yakni NP. Data (11) duo 'dua', (12) tigo 'tiga', berfungsi mengubah kata bilangan pokok dan bilangan penuh menjadi kata bilangan kumpulan (NK).

Dalam tataran sintaksis bentuk prefiks ke- yang dilekatkan pada kata bilangan, memiliki mengubah subklasifikasi NP menjadi NT atau NK. Dengan demikian, kaidah kemunculan prefiks ke- dengan kaidah: ke- + Num (NP). Sebagaimana telah disebutkan pada bagian terdahulu, posisi NK yang dibentuk dengan prefiks ke-, selalu berada di depan nomina, contohnya antara lain: keduo matoe, 'kedua matanya', ketigo budak tu. 'ketiga anak tu'. Berdasarkan contoh tersebut dapat dilihat bahwa kata bilangan kolektif yang dibentuk dengan prefiks ke- ,mengacu pada makna kumpulan yakni menyatakan kumpulan yang disebut D. Sedangkan kata bilangan tingkat dan urutan di bentuk dengan prefiks ke-,terletak sesudah nomina, antara lain: juaro keduo 'juara kedua' jukung ketigo 'perahu ketiga'. Dengan demikian, dalam tataran sintaksis subklaifikasi kata bilangan tingkat memiliki kaidah: $\mathrm{N}+\mathrm{ke}-$ + Num atau N+ (yang) ke- +Num.

\section{b) Polimorfemis dengan Sufiks}

Sufiks yang melekat pada D yang membentuk kata bilangan polimorfemis meliputi: 1) sufiks -e, dan 2) sufiks -an. Sufiks -e yang dilekatkan pada D yang berklasifikasi kata bilangan. Sedangkan sufiks -an melekat pada D yang berklasifikasi nomina. Sufiks e- yang melekat pada D, sama seperti prefiks ke-, sufiks ini hanya dapat melekat pada D yang sudah berklasifikasi kata bilangan. Fungsi sufiks -e tersebut hanya memberi penekanan pada kata bilangan yang dilekatinya. Oleh karena itu, dapat dikemukakan bahwa kaidah kemunculan sufiks -e yaitu: Num+ -e. Kaidah tersebut berlaku bagi data berikut:

(17) sekok+ -e ---> sekoke 'satunya'

(18). galo+ -e -----> galoe 'segalanya'

(19) segalo+ -e ----> segaloe 'segalanya'

(20). sebagian+ -e---> sebagiane 'sebagiannya'

(21) seluruh+ -e -----> seluruhe 'seluruhnya'

Sufiks -an hanya muncul dengan D yang berklasifikasi nomina. Sufiks ini berfungsi mengubah nomina menjadi kata bilangan yakni bilangan gugus. Dengan demikian sufiks -an meuncul dengan kaidah: Num + -an. Kaidah tersebut dapat dilihat antara lain pada data:

22) puloh+ -an ---> puluhan 'puluhan'.

23) blas+ -an -----> belasan 'belasan'. 
24) ratus+ -an -----> ratusan 'ratusan'.

25) ribu+ -an -----> ribuan 'ribuan'.

Selain itu Sufiks -an yang melekat pada D yang berklasifikasi nomina yang seperti pada data (22)--(25) dapat juga berfungsi membentuk kata bilangan kolektif (NK).

\section{c) Polimorfemis dengan konfiks}

Konfiks yang melekat pada D yang membentuk kata bilangan polimorfemis dalam penelitian ini hanya ditemukan satu bentuk yakni konfiks ke-e. Konfiks ini muncul dengan D yang berklasifikasi kata bilangan. Kaidah kemunculan konfiks ini adalah: ke- +Num -e. Kaidah ini berlaku untuk data berikut:

(28) keduoe 'keduanya',

(29) ketigoe 'ketiganya',

(30) kempate 'keempatnya'.

(31) keselusine 'keselusinnya', dan

(31) kesekodie 'kesekodinya'.

Bentuk dasar kata bilangan yang sudah mendapat konfiks $k e-e$ mengandung makna kolektif. Makna tersebut akan lebih jelas dalam tataran sintaksis, contohnya pada data berikut:

(32) bawaklah budak ko tu keduoe. Bawalah anak ini keduanya.

(33) Kerjokanlah soal ko ketigoe! "Kerjakanlah soal ini ketiganya!"

\section{d) Polimorfemis dengan Reduplikasi}

Kata bilangan polimorfemis yang dibentuk melalui reduplikasi (proses pengulangan) menghasilkan kata bilangan reduplikasi (NR). Dalam BMJ ada 2 tipe reduplikasi yaitu: (1) reduplikasi bentuk dasar tanpa afiks yaitu tipe D-D, (2) reduplikasi bentuk dasar berafiks yaitu tipe D-D+A. Berikut penjelasan kedua tipe reduplikasi tersebut.

(1) Reduplikasi tanpa afiks (Tipe D-D)

Kata bilangan polimorfemis tipe D-D dibentuk melalui proses reduplikasi tanpa afiks. Reduplikasi merupakan kata bilangan dasar tanpa perubahan bunyi apa pun. Kaidah reduplikasi tipe D-D dapat dilihat pada data berikut: 1) sekok-sekok 'satu-satu', 2) duoduo 'dua-dua', 3) tigo-tigo 'tiga-tiga', dan 4) galo-galo 'semua'. Bentuk reduplikasi ini sering digunakan dalam percakapan sehari-hari. Bentuk-bentuk tersebut dapat berdiri sendiri atau membentuk frasa kata bilangan.

(2) Reduplikasi dengan afiks (Tipe $D-D+A$ )

Reduplikasi kata bilangan dengan afiks atau reduplikasi tipe D-D+A mencakup tiga jenis yaitu: 1) reduplikasi dengan prefiks yaitu prefiks be-dan ke-, 2) reduplikasi bentuk dasar dengan sufiks $-e$, dan 3) reduplikasi bentuk dasar dengan konfiks ke-e.

(3) Reduplikasi dengan prefiks be-

Reduplikasi dengan prefiks be- pembentuk kata bilangan memiliki kaidah kemunculan prefiks be- + D-D. Kaidah tersebut dapat dilihat pada data berikut:

(36) Masuklah beduo-duo 'Masuklah berdua-dua',

(37) Iyolah betigo-tigo ' Iyalah bertiga-tiga',

(38) Bepuloh-puloh tahun yang lalu 'berpuluh-puluh tahun yang lalu',

(39) Beratus-ratus korban kehilangan rumahnya 'Beratus-ratus korban kehilangan rumahnya',

(40) Beribu-ribu taun yang "beribu-ribu".

(4) Reduplikasi dengan prefiks ke-

Reduplikasi dengan prefiks ke- dalam penggunaannya tidak dapat berdiri sendiri. Oleh karena itu, kaidah kemunculannya selalu dalam tataran frasa dan umumnya diikuti nomina. $\mathrm{Ke}+$ duplikasi $+\mathrm{N}$. Penerapannya terlihat pada data:

(41) keduo-duo anake 'kedua-duanya',

(42) ketigo-tigo adike 'ketiga-tiga adiknya', 
(43) ketujoh-tujoh 'ketujuh-tujuh dulure 'Ketujoh-tujoh saudaranya".

(5) Reduplikasi dengan sufiks

Bentuk reduplikasi kata bilangan dengan sufiks dalam BMJ jumlahnya terbatas yakni reduplikasi dengan sufiks - e. dengan kaidah tersebut ditemukan pada data yang terbatas yakni sekok 'satu' dan galo 'semua' perhatikan data berikut :

1. sekok-sekoke 'satu-satunya'

2. segalo-galo 'semua-semuanya'

Sesuai masalah dan hasil yang telah dikemukan dalam penelitian ini, maka pembahasan terkait dengan kalsifikasi bentuk-bentuk kata bilangan BMJ. Secara morfologi terdiri atas bentuk dasar dan bentuk turunan. Kedua bentuk tersebut dikaji berdasarkan struktur morfologinya sehingga menghasilkan bentuk monomorfemis dan polimorfemis. Kajian ini didasarkan pada kajian morfologis yang disebut word and paradigma (WP) dan item and process (IP). Dalam model kajian morfologis WP, satuan lingual kata diperlakukan sebagai satuan dasar dan unsur-unsur kata yakni morfem diperlihatkan secara tersirat. Dalam model ini misalnya, kata kedua disajikan bersama dengan kata lain yang mengandung bentuk inti (leading form) yang mirip: seperti beduo, manduo dan paduo.

Selanjutnya dalam kajian IP_diakui adanya dua komponen yaitu komponen dasar dan proses. Untuk kata bilangan kedua yang menjadi komponen dasar adalah duo. Bentuk ke-duo tersebut dalam BMJ merupakan hasil proses afiksasi berupa prefik ke- yang dilekatkan pada bentuk dasatr duo menjadi keduo "kedua" (Kridalaksana, 2005; Matthews, 1974; T Fatimah, 2006). Teori ini didukung oleh teori identifikasi morfem dari Nida (1979) yang dikutip Elson \& Pickett (1964), menurut teori ini morfem-morfem yang akan diidentifikasikan dibandingkan satu sama lain dengan memperhatikan bagian-bagian yang berulang dan dengan mengadakan subsitusi (J.S, 1993; Samsuri, 1994). Bagian yang berulang misalnya be- dari bentuk-bentuk beduo 'berdua' betigo 'bertiga' bempat 'berempat dan belimo 'berlima' di anggap sebagai bentuk yang disulih sehingga dapat dimasukkan ke dalam bingkai seperti:

$$
\text { be - } \mid \begin{gathered}
\text { duo } \\
+ \text { tigo } \\
\text { mpat } \\
\text { limo }
\end{gathered}
$$

Untuk menetapkan apakah bagian-bagian yang berada dalam bingkai sebelah kiri adalah kata atau bukan, dikaji dengan teori Lyons (2012). Teknik permutasi digunakan untuk mengidentifikasikan kata tersebut. Melalui ciri-ciri kata yaitu kebebasan bergerak dengan tetap mempertahankan identitasnya (positional mobility) dan keutuhan interen (internal cohesion). Bentuk-bentuk duo 'dua' tigo 'tiga' mpat 'empat' dan limo 'lima' mempunyai kebebasan bergerak dalam lingkungan yang lebih luas dan tidak dapat disisipi unsur lain. Oleh karena itu bentuk-bentuk tersebut adalah kata bilangan.

\section{PENUTUP}

Sesuai hasil dan pembahasan maka dapat disimpulkan bahwa: 1) Klasifikasi bentuk morfologi kata bilangan BMJ dapat dibagi menjadi dua berdasarkan jumlah morfemnya yaitu: 1) bentuk kata bilangan monomorfemis, bentuk ini secara morfologi terbentuk dari satu morfem, dan 2) kata bilangan polimorfemis. Klasifikasi bentuk monomorfemis dibedakan lagi berdasarkan jumlah silabel atau suku kata pembentuknya, yakni bentuk yang bersuku satu atau satu silabel, dua silabel, tiga silabel dan empat silabel. Sedangkan, klasifikasi bentuk kata 
bilangan polimorfemis dikelompokkan berdasarkan proses morfologi yang membentuknya yakni pembentukan melalui proseses afiksasi dan proses reduplikasi.

\section{DAFTAR PUSTAKA}

Alwi, H., Dardjowidjojo, S., Lapoliwa, H., \& M.Moeliono, A. (2003). Tata Bahasa Baku Indonesia. Balai Pustaka.

Anjarsari, R. R. (2015). Kata Bilangan Panentu Dalam Bahasa Sunda (Kajian Struktur dan Semantik). 6(5). https://doi.org/10.17509/jlb.v6i2.3169

Djawanei, S. (1983). Morfosintaksis. Bahan Ceramah Di Balai Penelitian Bahasa Yogyakarta.

Elson, B., \& Pickett, V. (1964). An Introduction to Morphology and Syntax (1st editio). Summer Institute of Linguistics.

Hockett, C. F. (1958). A Course In Modern Linguistics. Oxford \& IBH Publishing CO. https://doi.org/10.1111/j.1467-1770.1958.tb00870.x

J.S, B. (1993). Membina Bahasa Indonesia Baku 1 (Cet. 16). Pustaka Prima.

Kemendikbud RI. (2016). nu.me.ra.lia. Badan Pengembangan dan Pembinaan Bahasa. https://kbbi.kemdikbud.go.id/entri/numeralia

Kridalaksana, H. (2005). Kelas Kata Bahasa Indonesia. Gramedia Pustaka Utama.

Kusumawati, T. I. (2019). Numeralia dan Adjektiva dalam Bahasa Indonesia. Jurnal Nizhamiyah, IX(1), 59-77. http://jurnaltarbiyah.uinsu.ac.id/index.php/nizhamiyah/article

Lestari, S., Salem, L., \& Sanulita, H. (2017). Numeralia Bahasa Melayu Dialek Kapuas Hulu. Jurnal Pendidikan Dan Pembelajaran Khatulistiwa, https://jurnal.untan.ac.id/index.php/jpdpb/article/view/19830

Lyons, J. (2012). Introduction to Theoritical Linguistics. Cambridge at The University Press. https://doi.org/10.1017/CBO9781139165570

Matthews, P. H. (1974). Morfology an Introduction to Theory of Word-Structure. Cambridge University Press.

Nida, E. A. (1979). Morphology The Descriptive Analysis of Words (Second Edi). The University of Michigan Press.

Nurzuir, H. (1986). Morfosintaksis Bahasa Melayu Jambi. Pusat Pembinaan dan Pengembangan Bahasa, Depdikbud.

Nurzuir, H. (1986). Struktur Bahasa Melayu Jambi. Pusat Pembinaan dan Pengembangan Bahasa, Depdikbud.

R. Horn, L. (1989). A Natural Historis of Numerals. In Cambridge University Press. https://doi.org/10.1093/oxfordhb/9780198830528.013.20

Rahima, A., \& Juwanda, M. (2019). Bentuk Nomina Bahasa Melayu Jambi Di Desa Peninjau Kecamatan Bathin Ii Pelayang Kabupaten Muara Bungo Provinsi Jambi (Kajian Morfologi). Jurnal Ilmiah Pendidikan Bahasa dan Sastra Indonesia, 3(1), 8-15. https://doi.org/10.33087/aksara.v3i1.93

Samsuri. (1994). Analisis Bahasa: Memahami Bahasa Secara Ilmiah. Erlangga.

Shibatani, M. (2016). (Numeral) Classifier and Nominalization. Journal of Chemical Information and Modeling, 1(1), 11-12. https://catalogue.nla.gov.au/Record/7326080

Soulisa, I., S. Pormes, F., \& Manuputty, P. (2020). Analisis Kata Bilangan Bahasa Abun Ragam Abun Ta Distrik Bikar Kabupaten Tambrauw. Akrab Juara, 5(1), 27-37. http://akrabjuara.com/index.php/akrabjuara/article/download/939/830

Sudaryanto. (1992). Metode Linguistik: Ke Arah Memahami Metode Linguistik (Cet. ketiga). Gadjah Mada University Press.

T Fatimah, D. (2006). Detail Cantuman Text Metode Linguistik: Ancangan Metode Penelitian Refika Aditama: (Cet.2). Refika Aditama.

Tarigan, H. G. (1988). Numeralia dan Adjektiva dalam Bahasa Indonsia. In H. Lapoliwa \& S. R. H. Sitanggang (Eds.), Seminar Tata Bahasa Baku Bahasa Indonesia (pp. 61-83). Departemen Pendidikan dan Kebudayaan. 